\title{
First records of Lygaeus simulans Deckert, 1985 for Albania (Hemiptera: Heteroptera: Lygaeidae: Lygaeinae)
}

\author{
Torsten van der Heyden ${ }^{1 *}$, Paride Dioli ${ }^{2}$
}

\begin{abstract}
The first records of Lygaeus simulans Deckert, 1985 in Albania are reported. Additional information on the ecology (habitat preferences, host plants) and the distribution of this species is given.
\end{abstract}

Key words: Lygaeus simulans, Lygaeidae, Heteroptera, Hexapoda, Albania, occurrence records, faunistics.

Riassunto - Prime segnalazioni di Lygaeus simulans Deckert, 1985 per l'Albania (Hemiptera: Eterottera: Lygaeidae: Lygaeinae).

Sono riportate le prime segnalazioni di Lygaeus simulans Deckert, 1985 in Albania. Ulteriori dati sull'ecologia (habitat, piante ospiti) e sulla distribuzione di questa specie vengono altresì forniti.

Parole chiave: Lygaeus simulans, Lygaeidae, Heteroptera, Hexapoda, Albania, nuovi reperti, distribuzione faunistica.

\section{INTRODUCTION}

Lygaeus simulans Deckert, 1985 is morphologically very similar to the closely related Lygaeus equestris (Linnaeus, 1758). Both species occur sympatric and syntopic in various parts of the Palaearctic Region (Deckert, 1985; Péricart, 1998; Maschler, 2002).

Lygaeus simulans seems to prefer continental climates with dry and warm conditions (Deckert, 1985; Péricart, 1998; Rabitsch \& Deckert, 2008). The species has been found on Adonis vernalis L., Digitalis purpurea L. and Vincetoxicum hirundinaria Medik. (Deckert, 1985; Rabitsch \& Waitzbauer, 1996; Péricart, 1998; Rabitsch \& Deckert, 2008).

In Europe, L. simulans has been reported from the following countries: Austria, Bulgaria, Cyprus, the Czech Republic, France (including the island of Cor-

\footnotetext{
Immenweide 83, 22523 Hamburg, Germany.

${ }^{2}$ c/o Museo civico di Storia Naturale, Sezione di Entomologia, Corso Venezia 55, 20121 Milano, Italia.

E-mail: paridedioli@virgilio.it

* Corresponding author: tmvdh@web.de

(C) 2018 Torsten van der Heyden, Paride Dioli
}

Received: 16 March 2018

Accepted for publication: 5 September 2018

Online publication: 29 November 2018 sica), Germany, Great Britain (including the Channel Islands), Greece, Hungary, Italy, Kazakhstan (European part), Macedonia, Moldova, Poland, Romania, Russia (European part), Serbia, Slovakia, Spain, Switzerland and Ukraine (Deckert 1985; Lis, 1987; Kondorosy, 1989; Costas \& Vázquez, 1991; Gusev \& Tatarnikov, 1991; Josifov, 1990, 1993; Dioli et al., 1994; Rabitsch \& Waitzbauer, 1996; Péricart, 1998, 2001; Aukema, 2013).

\section{MATERIALS AND METHODS}

NW-ALBANIA. Theth (Lat: 42.383112, Lon: 19.791355), 21.VI.2014, 1 ex., photograph by Peter LaBelle (Fig. 1).

Looking among the material collected by the second author (P.D.) and colleagues in Albania during a scientific and mountaineering expedition carried out in 1993 (Dioli, 1993), it was possible to find a specimen of $L$. simulans with these label data:

NW-ALBANIA. Okol, scree at the base of Mount Maja Harapit, 1200 m, 12.VII.1993, 1 ex., male, legit F.Penati (P.Dioli Collection).

The photograph (LaBelle, Fig. 1) and the specimen male collected (leg. Penati, Coll. Dioli) in the same area were subject to a careful evaluation to highlight the particular characteristics that distinguish this species from $L$. equestris:

L. simulans: Bristles of the first antennal dense; portion of the head to the antennal insertion, protruding laterally. Black stripes of the head, close to the eyes, narrow. Frontal red part, wide. Bristles on the surface of scutellum of greater length than that of the remaining dorsal regions. The most visible characteristics, in the photograph, are the reduced presence of dark stripes on the head, near the eyes and the portion of the head, near the antennal insertion which is protruding laterally.

L. equestris: Bristles of the first antennal article sparse; portion of the head, at the antennal insertion, straight and slightly protruding. Black stripes of the head, near the eyes, wide. Frontal red part, narrow. Bristles on the surface of scutellum approximately equal to that of the remaining dorsal regions.

We also decided to examine the specimens of $L$. equestris collected by Livio Tamanini in Albania in 1941 


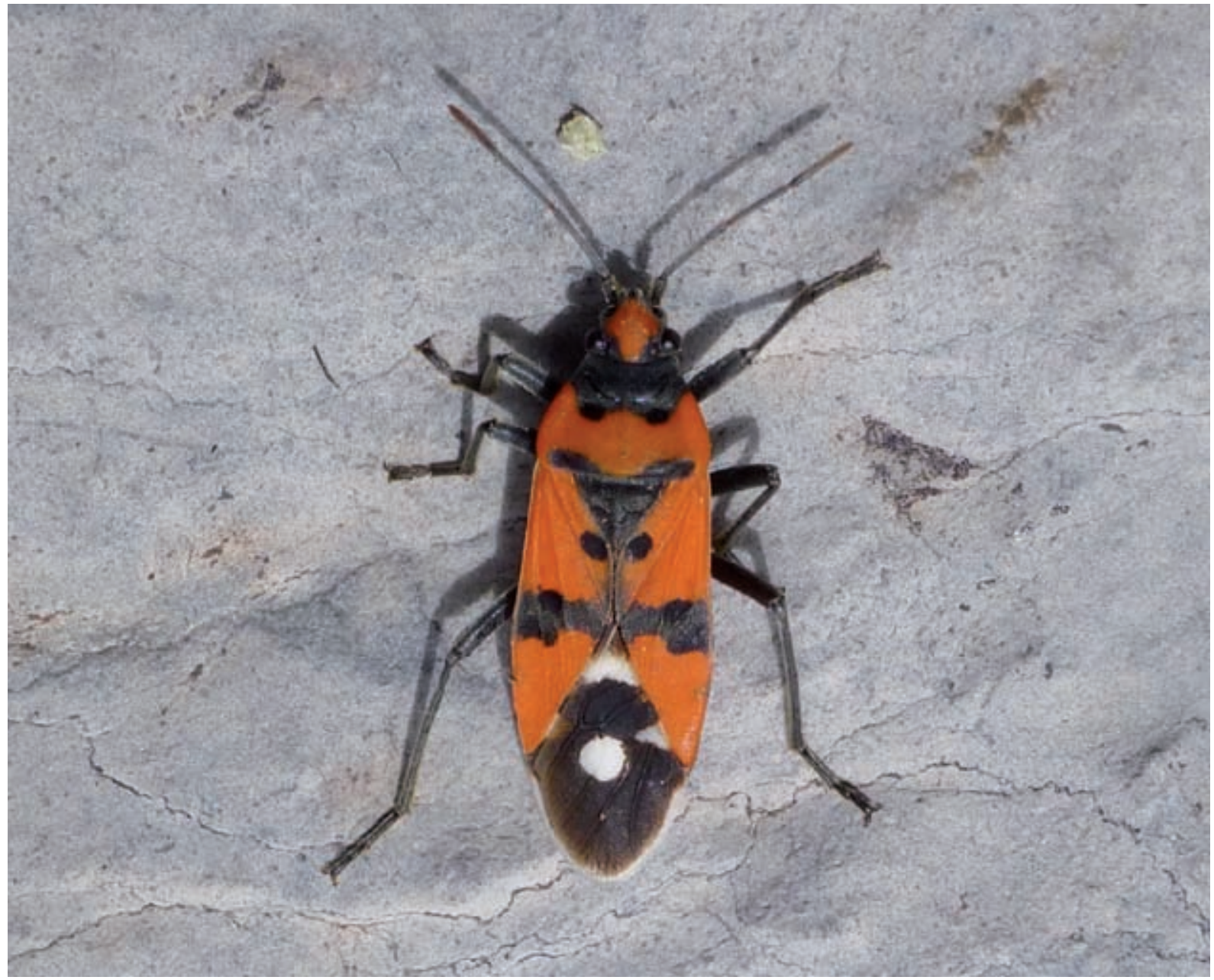

Fig. 1 - Specimen of Lygaeus simulans Deckert, 1985, mountains near Theth, Shkodër, Albania, 21.VI.2014. / Esemplare di Lygaeus simulans Deckert, 1985, montagne vicino a Theth, Shkodër, Albania, 21.VI.2014. (Photo / Foto: Peter LaBelle).

(Mancini, 1953). From a verification in Tamanini's collection at the Museum of Rovereto (Trento), no specimen of L. simulans emerged.

\section{DISCUSSION}

As L. simulans has not been reported from Albania in scientific publications after the date of description, the records reported in this paper are the first ones for this country.

The villages of Theth $(800 \mathrm{~m})$ and Okol (base of Mount Maja Harapit, $1200 \mathrm{~m}$ ) are not far from each other $(800 \mathrm{~m})$ (Fig. 2). Their altitude is compatible with most of the records of $L$. simulans mentioned in literature. Particularly in Southern Europe, findings of this species were generally made at locations between 700 and 1400-1500 $\mathrm{m}$ altitude, with a maximum of $2600 \mathrm{~m}$, which is considered outside the norm (Dioli et al., 1994).

The presence of $L$. simulans in plains and in large cities is rare and seems accidental, due to transport of logs (e.g. Florence, Rome) while, in its range, the presence of the species is confirmed almost exclusively in mountainous regions (Dioli et al., 1994). Therefore, even taking into account the ecological needs, the species seems to have a Euro-Centroasiatic distribution with a propensity for the mountains (Dioli et al., 1994).

Recently another species, Lygaeus creticus Lucas, 1854, was reported as new for Albania (van der Heyden, 2017). So, three species of the genus Lygaeus Fabricius, 1794 are currently known from Albania: L. creticus, $L$. equestris and L. simulans (Péricart, 2001; Aukema, 2013; van der Heyden, 2017).

\section{Acknowledgements}

We would like to thank Peter LaBelle (Thetford, Vermont, United States of America) and Giuseppe Popi Miotti (Sondrio, Italy) for allowing us to use their photographs to illustrate this paper. Furthermore, we would like to thank Petr Kment (National Museum, Department of Entomology, Prague, Czech Republic) for helpful information. Special thanks to our colleague heteropterist Filippo Maria Buzzetti (Museum of Rovereto, Trento, Italy) for the examination of the specimens collected by Livio Tamanini in Albania previously to the description of $L$. simulans. Finally, we would like to thank the anonymous reviewers for their suggestions to improve this paper. 


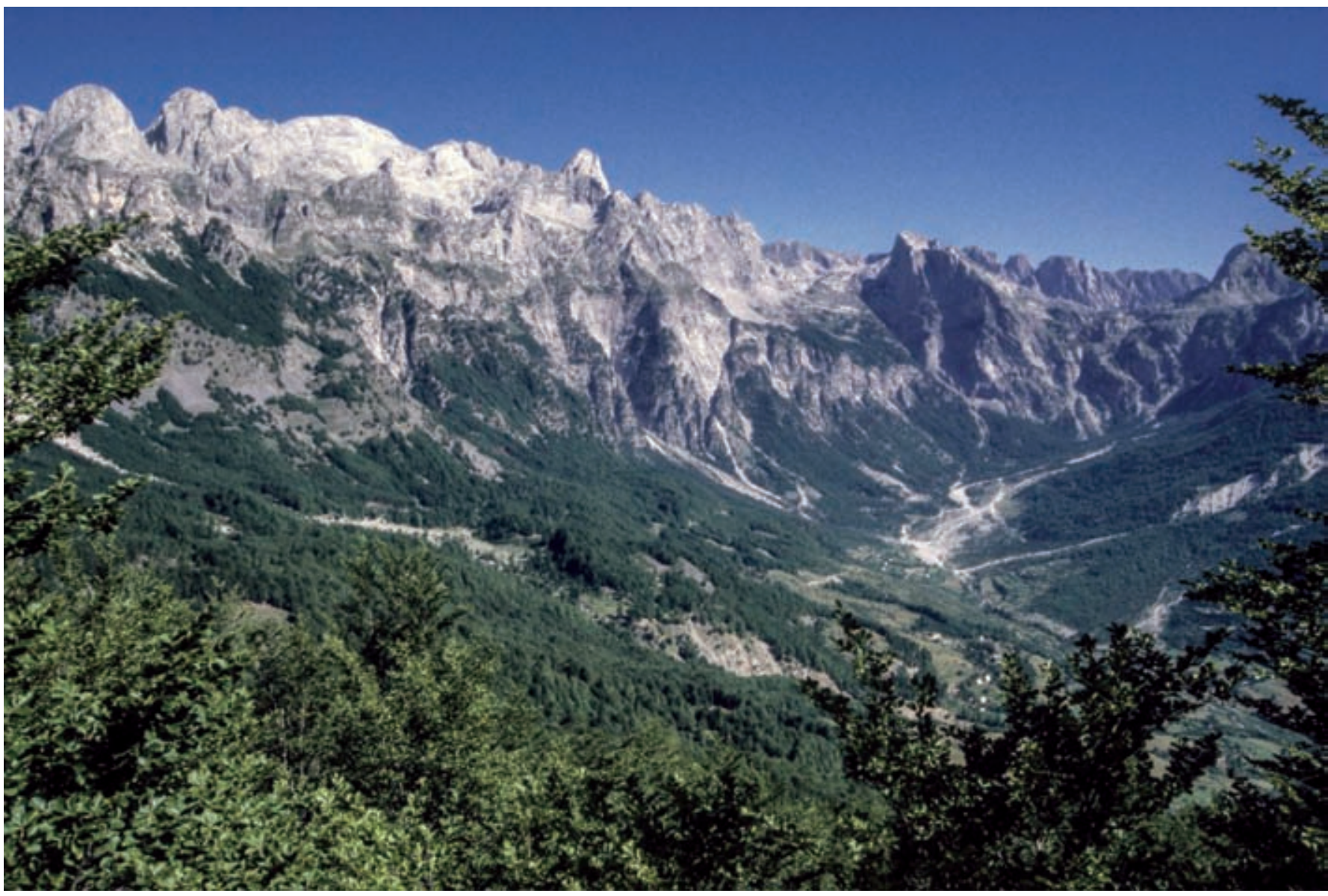

Fig. 2 - View of the valley of Theth, Shkodër, Albania. In the foreground the villages of Theth and Okol, in the background the chain of Mount Maja Harapit. / Vista sulla valle di Theth, Shkodër, Albania. In primo piano i villaggi di Theth e Okol, sullo sfondo la catena del monte Maja Harapit. (Photo / Foto: Giuseppe Popi Miotti, 1993).

\section{REFERENCES}

Aukema B., 2013 - Fauna Europaea: Hemiptera, Heteroptera. Fauna Europaea version 2017.06. <https:// www.fauna-eu.org > (last access: 3 March 2018).

Costas M. \& Vázquez M. A., 1991 - Nuevos datos sobre Lygaeus simulans Deckert, 1985 (Heteroptera, Lygaeidae) en la Península Ibérica. Anales de Biología, 17 (Biología Animal, 6): 23-28.

Deckert J., 1985 - Über Lygaeus simulans spec. nov. und L. equestris (Linnaeus, 1758), zwei nahe verwandte paläarktische Lygaeinae (Heteroptera, Lygaeidae). Mitteilungen aus dem Zoologischen Museum in Berlin, 61 (2): 273-278.

Dioli P., 1993 - Spedizione alpinistico-scientifica "Progetto Alpi Albanesi 1993". I. Ischnonyctes barbarus (Lucas, 1849) nuovo per i Balcani (Insecta, Heteroptera, Reduviidae) e osservazioni sui Metapterini Stal, 1874 europei. Il Naturalista Valtellinese - Atti del Museo civico di Storia naturale di Morbegno, 4: 17-24.

Dioli P., Faraci F. \& Rizzotti Vlach M., 1994 - Osservazioni morfologiche e corologiche su Lygaeus simulans Deckert, 1985 in Italia (Heteroptera: Lygaeidae). Atti del XVII Congresso nazionale italiano di Entomologia (Udine, 13-18 giugno 1994): 195-198.
Gusev R. V. \& Tatarnikov D. P., 1991 - On the distinguishing characters and distribution of the bugs Lygaeus simulans Deckert and L. equestris (Linnaeus) (Heteroptera, Lygaeidae). Entomologicheskoe Obozrenie, 70 (2): 404-406. [In Russian].

Josifov M. V., 1990 - Über die Verbreitung mancher Heteropterenarten auf der Balkanhalbinsel. III (Insecta). Acta Zoologica Bulgarica, 40: 3-11.

Josifov M. V., 1993 - Beitrag zur Verbreitung der Heteropteren auf der Balkanhalbinsel samt Bemerkungen über die Synonymie mancher Miridenarten (Insecta, Heteroptera). Acta Zoologica Bulgarica, 46: 50-58.

Kondorosy E., 1989 - A Lygaeus simulans Deckert bodobácsfaj előfordulása Magyarországon (Heteroptera: Lygaeidae). Folia entomologica hungarica, 50: 194.

Lis J. A., 1987 - Nowe i rzadkie w faunie Polski pluskwiaki różnoskrzydłe (Heteroptera, Pentatomomorpha). Przeglad Zoologiczny, 31 (3): 327-330.

Mancini C., 1953 - Contributo alla conoscenza degli Emitteri Eterotteri dell'Albania. Annalen des Naturhistorischen Museums in Wien, 59: 176-196.

Maschler B., 2002 - Ist Lygaeus simulans (Heteroptera, Lygaeidae) eine gute Art? Entomologica Austriaca, 5: 14. 
Péricart J., 1998 - Hémiptères Lygaeidae euro-méditerranéens. Volume 1. Généralités. Systématique: première partie. Faune de France. France et régions limitrophes. 84 A. Fédération Française des Sociétés de Sciences Naturelles, Paris.

Péricart J., 2001 - Superfamily Lygaeoidea Schilling, 1829. Family Lygaeidae Schilling, 1829 - Seedbugs. In: Catalogue of the Heteroptera of the Palaearctic Region. Volume 4. Pentatomomorpha I. Aukema B. \& Rieger Ch. (eds.). The Netherlands Entomological Society, Amsterdam, 35-220.
Rabitsch W. \& Deckert J., 2008 - Die Ritterwanze Lygaeus equestris Linnaeus, 1758 (Heteroptera: Lygaeidae) - das Insekt des Jahres 2007. Beiträge zur Entomofaunistik, 8 (2007): 212-218.

Rabitsch W. \& Waitzbauer W., 1996 - Beitrag zur Wanzenfauna (Insecta: Heteroptera) von Xerothermstandorten im östlichen Niederösterreich. 1. Die Hundsheimer Berge. Verhandlungen der Zoologisch-Botanischen Gesellschaft in Österreich, 133: 251-276.

van der Heyden T., 2017 - First records of Lygaeus creticus Lucas, 1854 (Hemiptera: Heteroptera: Lygaeidae: Lygaeinae) for Albania and France. Arquivos Entomolóxicos, 18: 65-66. 